\title{
Clean Laundry with Pure Conscience : A Study on Laundry Practices Among Finnish Consumers
}

\section{Miilunpalo, Satu-Marja}

2019-03

Miilunpalo , S-M \& Räisänen , R 2019 , ' Clean Laundry with Pure Conscience : A Study on Laundry Practices Among Finnish Consumers ' , International Journal of Consumer Studies , vol. 43 , no. 2 , pp. 153-165 . https://doi.org/10.1111/ijcs.12493

http://hdl.handle.net/10138/320411

https://doi.org/10.1111/ijcs.12493

unspecified

acceptedVersion

Downloaded from Helda, University of Helsinki institutional repository.

This is an electronic reprint of the original article.

This reprint may differ from the original in pagination and typographic detail.

Please cite the original version. 
DR. RIIKKA RÄISÄNEN (Orcid ID : 0000-0003-2918-3739)

Article type : Original Article

Clean Laundry with Pure Conscience - A Study on Laundry Practices Among Finnish

Consumers

\section{Running Head:}

Laundry Practices Among Finnish Consumers

Satu-Marja Miilunpalo ${ }^{1}$ and Riikka Räisänen ${ }^{1} *$

${ }^{1}$ Craft Studies, University of Helsinki, Finland

* Corresponding author. Craft Studies, P.O. Box 8, 00014 University of Helsinki, Finland, riikka.raisanen@helsinki.fi, Tel. +358 404132292

ORCHID: 0000-0003-2918-3739

This article has been accepted for publication and undergone full peer review but has not been through the copyediting, typesetting, pagination and proofreading process, which may lead to differences between this version and the Version of Record. Please cite this article as doi: 10.1111 ijes. 12493

This article is protected by copyright. All rights reserved. 


\begin{abstract}
The previous study concerning laundry practices in Finland was published 16 years ago. Since that time, many pro-environmental debates have been going on and sustainable actions have been implemented in many areas of individual lives and households. The purpose of this study is to investigate the textile laundering practices of Finnish consumers and their attitudes towards clothing care procedures. This study discusses how laundry habits could be developed into a more sustainable direction.
\end{abstract}

The data for this research were gathered through an online enquiry that consisted of structured multiple-choice questions. The data were obtained from 1841 persons of whom $97.5 \%$ were women $(n=1795)$. The data were analysed by statistical means using the SPSS program.

The data show that, despite media attention and debate about textile care procedures, there still are factors in laundering that burden the environment. From a sustainability point of view, some improvements exist when comparing to the situation 16 years ago, but washing machines still are seldom filled to their full capacity and consumers, being unaware of water hardness, administer excessive amounts of detergent. The current life situations of the household members seem to be major factors influencing laundry habits and sustainable actions. Especially young people and families with children would benefit from information and instructions on laundry practices. Topics could contain knowledge about water hardness and proper dosing of detergent, filling the washing machine, washing temperatures, drying 
methods and saving energy. Furthermore, general promotion of gender equality is important because household work and laundering is strikingly women-performed work.

Keywords: laundry; washing; textile; consumer; sustainability; quantitative analysis; Likert scale; gender equality

\section{Introduction}

It is estimated that two-thirds of textile's impact on the environment during its lifetime is developed during the use phase, i.e. in maintenance and laundering processes (Talvenmaa 1998; Fletcher 2009). Previous research show that culture has an enormous effect on how textiles are used and how they are maintained and washed (Arild et al. 2003; Spencer, Lilley and Porter 2015). Even though washing technology constantly advances, the new results and practices do not necessarily reach consumers and, especially, influence consumers to alter their habits. In order to change their habits, consumers need both knowledge and eagerness towards amendment (Laitala, Boks and Klepp 2011).

There are several studies about consumers' laundry habits in Europe, America, Asia and Australia (e.g. Arild et al. 2003; European Commission 2007; Laitala, Klepp and Boks 2012; Kruschwitz et al. 2014; Hecht and Plata 2016; Yates and Evans 2016; Laitala, Klepp and Henry 2017). However, in Finland only a few surveys exist, and the most recent was published in 2002 (Aalto 1998; Aalto 2002). In many studies, the focus has been on environmentally friendly washing and laundry procedures as well as washing technology and agents in processes, such as decreasing the use of energy, water and amounts of chemicals 
(Gooijer and Stamminger 2016; Hellmut and Dreja 2016; Lambert et al. 2016; Scheid et al. 2016; Abeliotis et al. 2015; Kalak and Cierpiszewski 2015; Honish, Stamminger and Bockmühl 2014; Schmitz and Stamminger 2014; Kruschwitz, Ausburg and Stamminger 2013; Laitala and Kjeldsberg 2012; Cameron 2011; Laitala, Boks and Klepp 2011).

An important aspect of textile care is how well the garment maintains its shape and appearance and remains in use. Studies show that garments that have lost these qualities are easily discarded (Räisänen 2014). One target for sustainable textile consumption is to increase the wear life of a garment. This can be reached when paying more attention to the textile maintenance and washing procedures. Creating meaningful garments and increasing the object relationship will lead to situations where textiles are taken better care of (Niinimäki 2010).

In her study, Aalto $(2002,82-84)$ found that the greatest challenges in laundering among her respondents were connected to several factors: people washed excessive amounts of clothes, machines were not fully loaded and clothes were not actually dirty. Furthermore, excess washing detergent was used because people did not know the hardness of water. These seem to be true also according to other investigations (Laitala, Klepp and Boks 2012).

In this research, the aim was to find out Finnish consumers' opinions about their laundry practices and how consumers estimated their deeds impact on environment. The study focused on what kind of textile care procedures and laundry practices consumers used, what kind of sustainable and pro-environmental actions were shown in consumers' laundry 
habits and, through discussion with the literature, figure out how consumers' laundry practices could be changed into more sustainable directions. The motivation for proenvironmental deeds is individual. Motivation directs individual's interests and action (Hamilton, Bower and Frijda 1988) and thus, the individual estimation of the extent of willingness gives valuable information about the practices and attitudes towards textile care processes. Results of this study were compared with Aalto's (2002) survey in order to see any changes in laundry practises over the past 16 years.

Sustainability has been determined to contain ecological, economic and social elements (e.g. UN 2018). Even though in this article the main emphasis of sustainability is in ecological aspects, the two other elements cannot be forgotten. Sustainable actions are understood to cover a wide range of deeds including those having economic, social and cultural impacts whereas pro-environmental actions are understood to deeds that have an impact primarily to the environment.

\section{Materials and Methods}

In this study, the data were collected in February 2017 through social media using an equestionnaire in Finnish. Because the results were aimed to be compared with Aalto's (2002) study, the e-questionnaire followed the structure and themes of her research. However, for this study the questions were modified further, for example to be answered using a Likert scale. Aalto's (2002) data consisted of the answers for a multiple choice and open questions questionnaire of 443 respondents, and 52 laundry diaries collected among the respondents. 
All quotes from open questions presented in this paper have been translated into English by the authors.

The link to the e-questionnaire was spread first in Facebook groups in which participants were assumed to be interested in answering the questionnaire, i.e. groups connected to recycling, mending textiles and sustainability. Participants were encouraged to spread the link further. The questionnaire was open 9 days, and during that time, 2026 answers were collected. After rearrangement of the data, i.e. deleting the forms that were saved multiple times, a total of 1841 answers were selected for the final study.

The enquiry contained 23 questions, which consisted of individual questions or sets of statements. The first questions (1-6) considered respondents' background information such as gender, age, family size and structure, residential area and dwelling type. Because the aim was to find out the strength of consumers' opinions, a 5-step Likert scale was used to survey laundry habits connected to detergent type, dosage and sorting of laundry (questions 7-9). The Likert scale consisted of 'fully disagree' (1), 'somewhat disagree' (2), 'insignificant' (3), 'somewhat agree' (4) and 'fully agree' (5). There were also multiplechoice questions concerning the frequency and the place of washing laundry (questions 11-13). Furthermore, there was a set of multiple-choice statements (question 14) that tried to discover consumers' textile care operations or what kind of actions consumers took to protect their clothing from getting dirty. It was possible to choose from a scale of 'never' (1), 'several times a year' (2), 'monthly' (3), 'weekly' (4) and 'nearly daily' (5). Questions 15-20 each contained a set of statements that surveyed consumers' laundering habits and for which respondents were able to choose from options 'hardly ever' (1), 'seldom' (2), 'often' (3) and 
'nearly always' (4). Questions surveyed, for example, conditions in which the garment was put into the laundry (15) and how clothes were sorted (16), filling the washing machine (17) and selecting the program (18). Also, drying habits were under investigation (questions 19-20). The last questions and sets of statements surveyed consumers' awareness about sustainability and environmental issues. Question 21 contained a set of statements for which Likert-scale answers running from 1 to 5 , as previously explained, could be selected. The question surveyed the tendency to change laundry habits and reasons for the possible change. The last questions (22-23) surveyed how much consumers had thought about the environmental effects of their laundry habits and whether they had a feeling that they could have an influence on the environment through their laundry actions. Both questions contained sets of statements for which options 'not at all' (1), 'a little bit' (2), 'quite much' (3) or 'very much' (4) could be chosen. For several multiple-choice questions, respondents were able to add a choice of their own. Furthermore, there were some open questions to which respondents could write their answer or give further explanation of the answer - for example, what clothes were washed by hand, a notable reason that had an effect on the laundry frequency, explanation for choosing washing temperatures and drying customs and feedback or comments concerning the questionnaire or any of the statements proposed.

The SPSS Statistics program (IBM, version 24) was used for quantitative data analysis. One-way variance analysis, Kruskal-Wallis test and post-hoc test were used to discover connections between selected background factors. Correlations (Pearson correlation) between factors were also looked for. For correlation, the limit of significance was placed in \pm 0.30 . 


\section{Results}

Demographic information of the respondents

The majority of the respondents were women (97.5\%), while 26 men (1.4\%) and 20 transgender/'other' (1.1\%) were included.

The age of respondents varied from 15 to 87 years, and different age groups were presented as described in Table 1. Most of the families included two adults living with children under 18 years (43.7\%) or without children (31.7\%). Single adult households with children under 18 years $(13.3 \%)$ or without children $(6.0 \%)$ were in the minority. Other types of households were recorded (5.3\%), such as two adults with adult children or shared apartments.

Table 2 (also Figure 1) shows the distribution of the respondents around the country. Most respondents were from southern Finland, which is in accordance with the population density (Statistics Finland 2018).

The most common household-dwelling types were blocks of flats $(40.4 \%)$, detached houses (38.2\%) and attached houses (19.9\%). Other dwelling types (1.5\%) were included, such as farms and shared apartments.

This article is protected by copyright. All rights reserved. 
Use of detergent

In previous research, the key challenges in laundering had been the dosage of washing detergent, which was excessive (Aalto 2002). This research aimed to find out whether this had changed, what were the most preferable qualities for detergents and how detergents were portioned. When asked about the factors that determined the selection of detergent (Figure 2), most respondents agreed strongly with the statement of buying unscented detergent $(63.6 \%$ fully agreed (fa) and $19.8 \%$ somewhat agreed (sa)). Respondents were a bit more conscious to choose detergents without zeolite $(45.2 \%$ fa and $23.1 \%$ sa) than to choose detergents without phosphate $(36.7 \%$ fa, $26.3 \%$ sa) or detergents with eco-labels $(28.2 \%$ fa, $33.7 \%$ sa). The examination of the correlations revealed that there was a significant positive correlation between those that chose the detergent without zeolite and detergent with an eco-label $\left(\mathrm{r}=.433^{* *}\right)$, showing that the respondents favoured detergent without zeolite and with an ecolabel.

The custom to always buy the same detergent brand was strong (32.9\% fa, $46.0 \%$ sa), as nearly $80 \%$ of the respondents agreed with this option fully or somewhat. For more than half of the respondents, the price of the detergent did not matter much when considering the detergent because $24.0 \%$ fully disagreed and $21.1 \%$ somewhat disagreed with the statement about cheap price and $18.7 \%$ considered the statement insignificant. The statement about buying whatever detergent was available showed that people cared about laundering and were conscious of their choices: about $80 \%$ disagreed fully or somewhat or called the statement insignificant. In an open question, participants were asked to describe other important selection criteria for detergents, and criteria such as vegan, anti-vivisection, 
domestic product, ecological and suitability for allergic people were named. For some, the form of the detergent, i.e. condensed powder or liquid, was important.

Figure 3 shows that there was not much difference between the preferences for the dosage of detergent. The most used course of action was to measure according to the instructions on the detergent package, for which about $50 \%$ of the respondents agreed. Almost as popular was to follow the measuring instructions the first time but then estimate the amount of detergent by ocular means thereafter. Furthermore, it was common to always use the same amount of detergent (45\% fully and somewhat agreed). Nearly the same portion (42\%) agreed that they did not measure the detergent but portioned by ocular estimate. Other reasons were the usage of 'considerably less' detergent than in the instructions and taking into account the dirtiness of the laundry.

The most important factors for the dosage of detergent were the amount of laundry, dirtiness of laundry, size of the washing machine and the hardness of water, respectively (Figure 4). For the separate question concerning the hardness of water $37 \%$ answered 'water is soft', whereas $38 \%$ answered that they did not know. Other options were 'semi-hard' $19 \%$ and 'hard' $5 \%$. The group of respondents that was the most unaware of the water hardness was young people aged 15 to 25 years (55\% of the total amount of unaware respondents). Kruskal-Wallis and post-hoc tests showed that there was a highly significant connection between the groups of respondents that did not know the water hardness and did not take water hardness into account when dosing detergent $(\mathrm{p}<.001 * * *)$ implicating that knowledge or lack of knowledge had an effect on the practices. 
Laundry habits

Washing machines run intensively in households. A little over half of the respondents (51.2\%) answered that they washed clothes several times a week, some (12.9\%) even every day. One-third (31.9\%) washed laundry every week. Only a small group of people $(3.9 \%)$ washed laundry monthly or even less often $(0.1 \%)$. Figure 5 shows that in most cases, laundry was washed in homes with own machines (95.4\%, once a month or more often). The laundry room of the housing cooperative was also used but only with a minority of the respondents (10.6\%, once a month or more often). Washing services were used very seldom among respondents. Only $2.3 \%$ of them used cleaners once a month or more often and even once a year only $6.0 \%$, whereas $61.5 \%$ never used cleaners and less than once a year $22.0 \%$. Launderettes were even more rarely used as $91 \%$ had never used them and only $0.3 \%(n=5)$ used them once a month or more often.

Nearly three of four households $(71.7 \%)$ washed laundry by hand at least once or twice a year. This and the open question revealed that even though there were hand and delicate wash programs in washing machines, woollen and silk garments were still often washed by hand. Only $12.1 \%$ of the respondents answered that they never washed by hand.

A majority of the respondents took some actions to take care of their clothes and

protect them from getting dirty (Figure 6). The most popular action was to use 'home clothing' to save better clothes from wear and getting dirty. Over half of the respondents $(56 \%)$ did this daily and nearly $80 \%$ weekly.

This article is protected by copyright. All rights reserved. 
It was quite common to protect garments in washing by turning them inside out (76\% did this daily or weekly) and using a wash bag (69\%). The analysis shows that these actions correlated significantly $\left(\mathrm{r}=.370^{* *}\right)$; those who turned clothes inside out also used wash bag.

There are several ways to refresh clothing without washing, such as airing and brushing. However, these were infrequent actions. Only $5 \%$ of the respondents did airing and $2 \%$ brushing daily; $20 \%$ and $8 \%$, respectively, weekly; and $34 \%$ and $17 \%$ once a month, whereas about $40 \%$ did airing and $74 \%$ brushing only a couple times per year or never. Examining correlations between these two factors showed that there was a significant correlation between them $\left(\mathrm{r}=.376^{* *}\right)$. Those who took care of their clothes in order to diminish washing took advantage of several kinds of protective actions.

Furthermore, using an apron or other garment as protective clothing had low popularity: $8 \%$ of the respondents used an apron daily, $15 \%$ weekly and $17 \%$ monthly, whereas around $60 \%$ used an apron only a couple times a year or never.

Stain removal before or at the same time as washing was a relevant course of action for about every third respondent.

In this survey, $53 \%$ of the respondents answered that they did not use softeners ever and $13 \%$ only a couple times per year. 
Respondents were not asked directly how many days they used different types of garments (cf. Laitala, Klepp and Boks 2012). Instead, they were asked a set of arguments for which they answered on a frequency scale varying from nearly always to hardly ever. Figure 7 shows reasons that clothing was put into a laundry basket. Self-evidently, most frequently washed pieces were underwear, also if the garment was obviously dirty or if there was a stain, which all obtained about $90 \%$ agreement among the respondents. The smell of usage or many days of usage were reasons to put clothes into the laundry nearly always or often; similarly, when the garment was used for a few days. Well over $80 \%$ of the respondents agreed with these frequencies. However, when asked about placing garments into the laundry after they had been used for one day, over half of the respondents (53\%) answered 'seldom' or 'hardly ever' and only $8 \%$ answered 'nearly always'.

Most commonly, laundry was washed according to colour (Figure 8). Over $70 \%$ of the respondents washed white, colourful and dark clothes separately nearly always (55\%) or often $(17 \%)$. Sorting by the temperature of the washing instructions was another common course of action (45\% responded nearly always, $31 \%$ often), whereas less common was to sort according to the fibre content (21\% nearly always, $33 \%$ often). Approximately half of the respondents sorted their laundry according to the use of the textile piece (18\% nearly always, $32 \%$ often). Only a minority of respondents (16\%) washed all their clothes together nearly always or often without doing any kind of sorting. The open question revealed that, for example, pets' clothes were washed separately from peoples' garments and bed linens separately from other textiles. Dirtiness seemed not to be a major reason for respondents to sort laundry because only about one-fourth of them used it as a criterion nearly always (7\%) or often $(19 \%)$.

This article is protected by copyright. All rights reserved. 
According to the results (Figure 9), it was clearly more common to load the washing machine loosely full (43\% responded nearly always, $37 \%$ often) than to load the machine as full as possible (23\% nearly always, $26 \%$ often). Washing only a few garments at a time was very rare among the respondents (95\% seldom or hardly ever).

Nearly 9 out of 10 respondents washed laundry according to the handling instructions nearly always (52\%) or often (37\%) (Figure 10). When examining the correlations between different factors in washing procedures, there was a significant correlation between sorting laundry according to washing temperatures and washing laundry according to the care label instructions $(\mathrm{r}=.549 * *)$.

The data showed that it was slightly more common to wash at a higher temperature than the handling instructions proposed ( $8 \%$ nearly always and $27 \%$ often) than to wash at a lower temperature ( $2 \%$ nearly always, $22 \%$ often). Furthermore, there was a group of people, who always used the same temperature for all garments, as $9 \%$ of the respondents washed nearly always and $19 \%$ often in the same temperature. Only a very small minority (3\%) did not care about the washing temperature (Figure 10). The open question revealed that the most common temperatures were $60^{\circ} \mathrm{C}(n=826)$ and $40^{\circ} \mathrm{C}(n=267)$. Many respondents washed bedlinens, towels and baby clothes in $60^{\circ} \mathrm{C}$ or sometimes even in $90^{\circ} \mathrm{C}(\mathrm{n}=11)$. There were many comments that revealed that normal clothes, and even all laundry, was washed in $60^{\circ} \mathrm{C}$. Only a few $(\mathrm{n}=22)$ used the $30^{\circ} \mathrm{C}$ for clothes. The open question also showed that some of the 
respondents did not believe the clothes to become clean in a $30^{\circ} \mathrm{C}$ washing program or cotton even in $40^{\circ} \mathrm{C}$, as stated by the following quotes:

Temperatures in care labels are often too cautious and we wash everything usually in $40^{\circ} \mathrm{C}$ (woman, 38 years).

All clothes endure $60^{\circ} \mathrm{C}$ and become cleaner (woman, 29 years).

In the machine, there is a $60^{\circ} \mathrm{C}$ Power program with an extra rinsing which takes 1 hour 19 minutes. All laundry is washed with that program except baby napkins (woman, 40 years).

Temperature under 60 degrees won't release sweat and grease (woman, 39 years).

Furthermore, the care labels for $30^{\circ} \mathrm{C}$ washing were disregarded because the machine was not full, and thus, clothes were combined and washed in a higher temperature of $40^{\circ} \mathrm{C}$. Washing in $30^{\circ} \mathrm{C}$ was mainly for wool, silk and delicate items; however, $30^{\circ} \mathrm{C}$ was also for clothes by some respondents in cases where they were not dirty.

Drying laundry

Respondents were presented statements concerning different ways of drying laundry both in the summer and winter (Figure 11). Inside line drying was distinctly the most common way of drying laundry all year round. In the summer, $69 \%$ of the respondents did so nearly always or often and in winter $86 \%$. Line drying outside was in summer the second-most popular way of drying ( $26 \%$ nearly always and $26 \%$ often), but in winter it was hardly used (1\% nearly always (na), $2 \%$ often (o)), which is understandable because in Finland the temperature stays 
below zero several months, from November to April (Finnish Meteorological Institute 2018). Drying in a tumble dryer was used slightly more commonly in winter than in summer; in winter, about every third respondent used a dryer (20\% na and $13 \%$ o), whereas in summer every fourth (13\% na, $11 \%$ o). The difference is not much, and it shows that those who actively used a tumble dryer used it year round $\left(\mathrm{r}=.895^{* *}\right)$. When comparing different household types, households with children used tumble dryers more often both in the summer ( $18 \%$ na and $13 \%$ o) and in winter ( $28 \%$ na, $15 \%$ o) than adult-only households (in summer $9 \%$ na and $9 \% \mathrm{o}$; in winter $12 \%$ and $11 \%$, respectively) $\left(\mathrm{p}<.001 ; \mathrm{X}^{2}\right)$. This could be clarified by a statement from one respondent:

In a household with children, a tumble dryer is absolutely important, and it makes laundering more effective but unfortunately not very ecological (woman, 26 years).

A small number of respondents used a drying room of a housing cooperative both in summer (2.8\% nearly always and $4.4 \%$ often) and winter (3.5\% na and $5.1 \%$ o). Furthermore, the figures show that drying cabinets are not very popular in Finland, as over $95 \%$ of the respondents had never used one. The recent development in washing machines is the combination of washer and dryer in the same machine. Only $2 \%$ of the respondents used drying in an all-in-one machine nearly always or often and over $96 \%$ hardly ever. In addition, the figures were the same for both winter and summer. This shows that all-in-one machines were quite rare among the respondent group (Figure 11).

This article is protected by copyright. All rights reserved. 
Change in laundry habits

Respondents were asked to estimate the change in their laundry habits in recent years. In this research, two-fifths of the respondents (41\%) fully agreed that nothing had changed in their laundry habits and altogether $72 \%$ somewhat agreed or reported 'no change' (Figure 12). The change in the household size and the machinery had more often caused changes in laundry habits. For almost half of the respondents, the desire to save the environment (19\% fully agree and $26 \%$ somewhat agree) and energy (18\% fa, $27 \%$ sa) were reasons to change laundry habits, whereas $14 \%$ disagreed fully or to some extent with these aspects. When examining the correlations between different factors, the strongest correlation was found between those who desired to save the environment and those who wanted to save energy $(\mathrm{r}=.825 * *)$.

The open question revealed that other reasons for changes were connected to the number of children in the family. The birth of a baby and usage of cloth napkins increased the amount of laundry, whereas the adulthood of a child and moving away from home decreased it. Also, allergies to chemicals, changing to unscented detergents and buying a tumble dryer influenced laundry habits.

At the end of the questionnaire, the respondents were asked if they had been thinking about the environmental aspects of their laundry habits and if they felt that they could have an effect on the environment through their actions. There was a slightly greater optimism in the feeling that consumer's choices affect the environment than when evaluating his/her own pro-environmental thoughts (Figure 13), as the percentages of 'not at all' answers were slightly smaller when evaluating the hope of the effectiveness in general (4-9\% "not at all' answers Figure 13 bottom) compared to the own thoughts (12-23\% 'not at all' answers 
Figure 13 top). According to Figure 13, the majority (about $80 \%$ or even more) of the respondents thought at least a little bit about different aspects of laundering that would have an effect on the environment. The most effective pro-environmental deeds were connected to choosing detergent and portioning it. Furthermore, pro-environmental thinking affected filling the washing machine; this same aspect came out also in open statements, where many wished to wash only full loads of dirty clothes. Whereas buying a washing machine, deciding whether to wash a garment and choosing the washing temperature did not receive high confidence because about every fifth (21-23\%) respondent believed that they could not have an effect on the environment through these actions. Altogether, the majority, over $90 \%$, of the respondents felt that they could have an effect on the environment through their laundry deeds at least to some extent.

\section{Discussion}

This study was based on the previous survey of Aalto (2002). In this way background information was available and reliability enhanced (Metsämuuronen 2011). Even though the gathering of the data was not the same as Aalto's and questions were modified further, it can be estimated that the results obtained from this study are in accordance and they can be roughly compared with the previous study. The e-questionnaire contained 23 questions or sets of statements. The feedback of the respondents revealed that the questionnaire was lengthy and some had difficulties in concentrating to fill it fully. Nevertheless all answers accepted to the study were complete $(\mathrm{N}=1841)$. For the validity point of view the equestionnaire can be evaluated to fulfil the research strategy, i.e. that the questionnaire measured the aspects that it was intended to (Metsämuuronen 2011). The questionnaire was spread through Internet's social media and this has a decreasing effect on the reliability of the 
results. It is likely that the sampling is skewed and respondents that were particularly interested in sustainable issues and textile care were over represented. However, the number of respondents is good and demographic information shows that the sample is representative. Results may not be generalised to whole population but they are interesting and give valuable information about the laundry practises among Finnish households.

The majority of the respondents were women (97.5\%) while 26 men (1.4\%) and 20 transgender/'other' $(1.1 \%)$ were included. These figures show that women are active in social media, especially in groups dealing with recycling, mending textiles and sustainability. Women, compared to men, may also be more eager to answer surveys that deal with issues that are important to them or they are most involved with. In recent statistics, women were found to be slightly more active in social media groups than men (62\% vs. 59\%, respectively) (OSF 2017). Even though Finland is considered one of the most gender-equal societies in the world (MSAH 2018; EIGE 2017), in household activities, especially laundering, customs are relatively women dominant. The gender equality survey ordered by the Ministry of Social Affairs and Health in Finland (Kiianmaa 2012) shows that laundering is considered to be $80 \%$ women's responsibility in $60 \%$ of the families. This may also be a reason why the majority of respondents were women.

The gender gap in women's and men's engagement in cooking and housework activities has been consistently and strikingly high in the European Union (EU) area. In Finland, nearly 55\% of men engage in cooking and housework every day for 1 hour or more, compared with $85 \%$ of women (EIGE 2017); thus, the gender gap is around $30 \%$. More importantly, statistics show that over the last 10 years, there have been almost no 
improvements towards gender equality in this area across the EU (EIGE 2017). The widest gender gap can be found in couples with children. However, even in couples without children, the difference between women's and men's engagement in housework is strikingly high. In contrast, the smallest gender differences in housework engagement are among single women and men and single parents (EIGE 2017). From the sustainability point of view (UN 2018) equality in housework activities would need further research and promotion.

When comparing the results of this research and Aalto's (2002) study, it can be estimated that the environmental consciousness among consumers has risen in 16 years. The answers show that peoples' pro-environmental thoughts and actions are stronger and they have started to take environmental aspects more into consideration in their laundry habits. In Aalto's $(2002,74)$ study, a slightly smaller percentage of respondents, compared to this study, estimated that saving the environment (11\%) and energy (14\%) had changed their laundry habits (cf. circa half of the respondents agreed fully or somewhat in this study).

Nevertheless, excessive washing of garments is still quite common: machines are not full when washing and clothes are not clearly dirty. The appearing softness and the loss of fit and firmness of the fabric could be reasons for unnecessary laundry, as concluded from the high percentages of agreement (83\% nearly always or often, Figure 7) for statements concerning 'the odour of wear' as a reason for washing. Conclusions made based on Figure 7 show a frequent tendency to unnecessarily wash garments. This is universal and is in accordance with previous research (Laitala, Klepp and Boks 2012; Kruschwitz et al. 2014; Spencer, Lilley and Porter 2015). In spite of the tendency to increased washing there are encouraging signs that consumers try to use garments several times before washing, which 
was revealed by the high percentages of answers (53\% 'seldom' or 'hardly ever' and only $8 \%$ 'nearly always') indicating that garments were placed seldom into the laundry after one day usage.

Studies among European consumers show that people do not have a very clear understanding of the hardness of water and what it has to do with laundering. In Aalto's (2002) study, 45\% of the respondents did not know the hardness of water. Similar results were observed by Kruschwitz et al. (2014), where over half of the German respondents, and Laitala, Klepp and Boks (2012), where $63 \%$ of the Norwegian respondents, did not know the hardness of water in their areas. This research had a separate question about the hardness of water, for which $38 \%$ answered that they did not know and $37 \%$ answered correctly 'water is soft'. In Finland, 95\% of the water is soft (Vellamo 2018). There are areas where the water hardness is semi-hard, but it is unlikely that one-fifth of the respondents, who selected that option, lived in these areas; on the other hand, the boundary between soft and semi-hard is narrow: $\leq 5^{\circ} \mathrm{dH}$ is considered soft, whereas $5.5^{\circ} \mathrm{dH}$ semi-hard (Vellamo 2018). Compared to the situation 16 years ago (Aalto 2002), Finnish consumers seem to be slightly more aware of the water hardness.

Futhermore, pro-environmental action was observed in choosing detergent as the detergent without zeolite rose to the second-most important selection criteria in this study. Previously it did not have that much importance (Aalto 2002). Also, protective actions such as turning clothes inside out and using a wash bag seemed to have gained popularity; on the contrary hand washing had slightly decreased. 
Use of softeners has decreased recently. In Aalto's (2002) study, 56\% of the respondents used softener weekly or more often, whereas in this study, only $14 \%$ used it in a similar frequency. One reason for the decrease in using softeners in washing might be the increase of elastomers in all kind of fabrics. Approximately $80 \%$ of clothing sold in the United States in 2010 contained elastomers, and the producing volume of the fibre is still increasing (Peñaloza 2011; Wikipedia 2018; Innovation in Textile 2017). Elastomers suffer from softeners, and their elasticity and strength is decreased (Räisänen et al. 2017; Chiweshe and Crews 2000). This seems to be relatively well known among Finnish consumers because there have been many articles and programs about the topic in the media (e.g. MTV 2.1.2014; Helsingin Sanomat 25.8.2015; Martat 2018), and the results of this study strengthen this assumption. Also, the desire to decrease the overall chemical load could be another reason (cf. Martat 2018).

It has been discovered by a previous study (Laitala, Boks and Klepp 2011) that consumers are reluctant to fully fill the machine in fear of bad washing results or because sorting systems result in a lack of suitable items to be washed at the same time. Also, full loading diminishes washing results compared to loosely filling (Laitala, Boks and Klepp 2011). There was a desire to wash full loads among respondents and this was reached by combining laundry of different temperatures, e.g. 30 and $40^{\circ} \mathrm{C}$. However, it is not clear how well the respondents estimated the fullness of their washing machine. More reliable results could have been obtained by measuring the weight of the laundry.

This article is protected by copyright. All rights reserved. 
This study shows (Figure 10) that consumers (9 out of 10) quite obediently follow the temperatures and instructions on care labels and this trend has slightly increased compared to the results from 16 years ago (Aalto 2002) where three out of four consumers washed their laundry mainly according to the temperatures on the care labels. However, there seems to be a group of consumers who like to use the same temperature for all garments. This may be due to the popularity of cotton in all kinds of textiles. Furthermore, many respondents washed their laundry in $60^{\circ} \mathrm{C}$ just to be on the safe side. This assumption was strengthened by the open comment as can be seen in the following:

$100 \%$ cotton in $60^{\circ} \mathrm{C}$ even though the label would say $40^{\circ} \mathrm{C} .$. Cotton won't become clean in a lower temperature (woman, 59 years).

From the sustainability and ecological point of view (UN 2018) lowering washing temperatures decreases energy consumption and consumers courses of action are important in this respect, not only the development of more energy efficient washing machines (Schmitz and Stamminger 2014). The heating of water is widely recognized as the most energy intensive process taking place in washing machines (Laitala, Boks and Klepp 2011; Yates and Evans 2016). Because textiles are more and more washed for refreshing, and not because they are truly dirty, it could be beneficial to add information to the manufacturers' care labels, for example to propose lighter washing, i.e. in lower temperature with less detergent. Also drying consumes energy. There are estimations about different drying techniques and their energy demand (Pedersen, Labhard and Webb 1988; Laitala, Boks and Klepp 2011; Yun et al. 2017), but results are not unambiguous, nor showing favour to any particular drying method, because phenomena are complicated and there are many factors (i.e. fiber type, 
structure of the fabric, spinning speed etc.), which have an effect on the results. Furthermore, for a consumer appropriate drying method seem to be depended on such factors as weather, sensory considerations as well as 'freshness' or 'fluffiness' of clean textiles (Yates and Evans 2016; Yun et al. 2017). For a consumer variety of choices is vast and therefore material knowledge and information about the washing and drying characteristics of different fibre types could be provided more to help in decision making.

In this study, about every fifth $(21-23 \%$ of the respondents answering to the following three questions 'not at all', Figure 13) respondent estimated that they could not have an effect on the environment through their own actions, such as when estimating whether to wash the garment, when choosing the washing temperature or when buying a washing machine. This shows that there is a need for more information, and there could be much more done to encourage people on even small pro-environmental actions through different social and cultural campaigns (cf. Laitala, Klepp and Boks 2012; Räisänen and Laamanen 2014). Altogether, the majority, over $90 \%$, of the respondents felt that they could have an effect on the environment through their laundry deeds at least to some extent. This is important when thinking about the empowerment of consumers. According to Salonen (YLE News 2018), sustainable deeds increase peoples' satisfaction and feeling that their lives are purposeful. When making sustainable choices, people feel like active players rather than passive followers. An active person makes what is appropriate from his/her own basis. Satisfaction and sustainable deeds are also connected the other way around: A content person makes sustainable choices. Salonen describes this as the circle of good (YLE News 2018).

This article is protected by copyright. All rights reserved. 


\section{Conclusions}

The results of this study show that environmental awareness has increased in recent years. The desire to choose detergent without zeolite and phosphate and a brand that has an ecolabel is greater now than before. Furthermore, respondents were more aware of the hardness of water compared to previous studies. However, there still are consumers unaware of the hardness of water and its influence on the dosage of the detergent.

Because excessive washing of garments is quite common there could be an order for consumer advisory concerning other ways of refreshing garments, such as airing, brushing and steaming. Also, information about energy, water and chemical consumption could be increased. It seems that sustainable decisions and deeds would make a greater breakthrough if they were considered more as subjects that increase people's own satisfaction and self-esteem than subjects of demands and requirements. Therefore, encouraging, inspiring and personal education would be needed to help individuals rethink, evaluate and change their habits.

The majority $(97.5 \%)$ of the respondents in this study were women, which reflects the current statistics about household work. For the sustainability, it is important to promote general gender equality and unbiased division of household work. This aspect would be important to discover in the future studies.

This article is protected by copyright. All rights reserved. 


\section{References}

Aalto, K. (1998) Vaatteiden käytön ja hoidon ympäristövaikutukset - tuoteinformaatio ja kuluttajien valintamahdollisuudet [Enviromental effects of textiles' use and care product information and consumers' options]. Kuluttajatutkimuskeskus, Helsinki.

Aalto, K. (2002) Kotitalouksien tekstiilien hoitokäytännöt ja niiden ympäristömyötäisyys [Households' Textile Care Practices and Their Environmental Friendliness]. Kuluttajatutkimuskeskus, Helsinki.

Abeliotis, K., Candan, C., Amberg, C., Ferri, A., Osset, M., Owens, J. and Stamminger, R. (2015) Impact of water hardness of consumers' perception of laundry washing result in five European countries. International Journal of Consumer Studies, 39: 60-66.

Arild, A-H. (ed.), Brusdal, R., Halvorsen Gunnarsen, J. T., Terpstra, P. M. J., and van Kessel I. A. C. (2003) An Investigation of Domestic Laundry in Europe. Habits, Hygiene and Technical Performance. Fagrapport nr. 1. SIFO, Oslo.

Hamilton, V., Bower, G. H. and Frijda, N. H. (eds.) (1988) Cognitive perspectives on emotion and motivation. Springer.

Cameron, B. A. (2011) Detergent considerations for consumers: laundering in hard water How much extra detergent is required? Journal of Extension, 49(4): 1-11.

Chiweshe, A. and Crews, C. P. (2000) Influence of household fabric softners and laundery enzymes on pilling and breaking strength. Textile Chemist and Colorist and American Dyestuff Reporter, 32(9): 41-7.

European Commission (2007) (Tender TREN/D1/40-2005). LOT 14: Domestic Washing Machines \& Dishwashers. Final report. Draft version, tasks 3-5: 230-431. 
EIGE (European Institute for Gender Equality) (2017) Gender Equality Index 2017. [Cited 2018 March 27]. Available from: http://eige.europa.eu/gender-equality-index.

Finnish Meteorological Institute (2018). [Cited 2018 July 23]. Available from: http://ilmatieteenlaitos.fi/kuukausitilastot.

Fletcher, K. (2009) Sustainable fashion \& textiles. Design Journeys. Earthscan, London.

Gooijer, H. and Stamminger, R. (2016) Water and Energy Consumption in Domestic Laundering Worldwide - A Review. Tenside, Surfactants, Detergents, 53(5): 402-408.

Hecht, M. and Plata, S. (2016) Washing Expectations in Domestic Laundering - Consumer Behavior in Mexico. Tenside, Surfactants, Detergents, 53(5): 417-423.

Hellmut, H. and Dreja, M. (2016) Understanding interactions of surfactants and enzymes. Tenside, Surfactants, Detergents, 53(5): 502-507.

Helsingin Sanomat (2015) Pesuaine voi tärvellä treeniasun - huuhteluaineet kannattaa unohtaa [Washing powder may destroy workout clothing - fabric softeners can be forgotten]. Helsingin Sanomat 25.8.2015. [Cited 2018 July 23]. Available from: https://www.hs.fi/elama/art-2000002847554.html.

Honisch, M., Stamminger, R. and Bockmühl, D. P. (2014) Impact of wash cycle time, temperature and detergent formulation on the hygiene effectiveness of domestic laundering. Journal of Applied Microbiology, 117(6): 1787-1797.

Innovation in Textile (2017) Spandex fibre market expected to reach US\$ 10,482 million by 2022. [Cited 2018 March 29]. Available from: http://www.innovationintextiles.com/spandex-fibre-market-expected-to-reach-us10482-million-by-2022/.

This article is protected by copyright. All rights reserved. 
Kalak, T. and Cierpiszewski, R. (2015) Correlation analysis between particulate soil removal and surface properties of laundry detergent solutions. Textile Research Journal, 85(18): 1884-1906.

Kiianmaa, N. (2012) Tasa-arvobarometri [Equality Barometer]. Publications of the Ministry of Social Affairs and Health 2012:23. Ministry of Social Affairs and Health, Helsinki. [Cited 2018 March 19]. Available from: http://urn.fi/URN:ISBN:978-952-00-3370-5.

Kruschwitz, A., Ausburg, A. and Stamminger, R. (2013) How effective are alternative ways of laundry Washing? Tenside, Surfactants, Detergents, 50(4): 263-269.

Kruschwitz, A., Karle, A., Schmitz, A. and Stamminger, R. (2014) Consumer laundry practices in Germany. International Journal of Consumer Studies, 38: 265-277.

Laitala, K., Boks, C. and Klepp, I. (2011) Potential for environmental improvements in laundering. International Journal of Consumer Studies, 35: 254-264.

Laitala, K. and Kjeldsberg, M. (2012) Cleaning effect of alternative laundry products. A comparison of soap nuts, laundry balls, washing pellets, laundry magnets, water and regular detergent. Household and Personal Care Today, 7(4): 53-56.

Laitala, K., Klepp, I. and Boks, C. (2012) Changing Laundry Habits in Norway. International Journal of Consumer Studies, 36: 228-237.

Laitala, K., Klepp, I. G. and Henry, B. (2017) Use phase of wool apparel: a literature review for improving LCA. In: Product Lifetimes and the Environment 2017 - Conference Proceedings (ed. by C. Bakker and R. Mugge). Delft University of Technology and IOS Press, Delft. DOI: 10.3233/978-1-61499-820-4-202.

Lambert, E., Maitra, W., Scheid, F., Niestrath, M., Gorny, S. and Stamminger, R. (2016) Differentiated evaluation of washing performance in washing machines of test stain 
strips as a function on temperature, washing duration and load size. Tenside, Surfactants, Detergents, 53(5): 424-437.

Martat 2018. Pyykinpesuaineet [Detergents]. [Cited 2018 July 23]. Available from: https://www.martat.fi/marttakoulu/kodinhoito/pyykki/pyykinpesuaineet/.

Metsämuuronen, J. (2011) Tutkimuksen tekemisen perusteet ihmistieteissä [Essentials of research methods in human sciences]. International Methelp, Helsinki.

MSAH (Ministry of Social Affairs and Health) (2018) Gender equality. [Cited 2018 March 19]. Available from: http://stm.fi/en/gender-equality.

MTV (Mainostelevisio) (2014) Pese oikein - älä käytä huuhteluainetta näihin [Wash clothes in a right way - do not use fabric softener on these]. MTV 2.1.2014. [Cited 2018 July 23]. Available from: https://www.mtv.fi/lifestyle/koti/artikkeli/pese-oikein-ala-kaytahuuhteluainetta-naihin/3197762\#gs.Fo1LlOM.

Niinimäki, K. (2010) Eco-Clothing, Consumer Identity and Ideology. Sustainable Development 18: 150-162.

OSF (Official Statistics of Finland) (2017) Use of information and communications technology by individuals. Statistics Finland, Helsinki. [Cited 2018 March 27]. Available from: http://www.stat.fi/til/sutivi/index_en.html.

Pedersen, E. L., Labhard, L. A. and Webb, J. (1988) Line-drying vesus machine-drying: energy consumption comparison. International Journal of Consumer Studies \& Home Economics, 12(4): 349-360.

Peñaloza, M. (2011) Spandex Stretches to Meet U.S. Waistlines. New York: NPR. [Cited 2018 March 29]. Available from: https://www.npr.org/2011/12/11/143003539/spandexhas-stretched-with-u-s-waistlines.

This article is protected by copyright. All rights reserved. 
Räisänen, R. (2014) Wardrobe inventory - a way to increase consciousness towards textile consumption. In: Proceedings of Ambience14 \& 10i3m Scientific Conference for Smart and functional textiles, Well-being, Thermal comfort in clothing, Design, Thermal Manikins and Modelling, 7-9 Sep 2014 Tampere, Finland (ed. by M. Varheenmaa), ID168. Tampere University of Technology, Tampere.

Räisänen, R. and Laamanen, T. K. (2014) Tieto, kritiikki, toiminta, vastuu - pohdintaa kestävän kehityksen ja eettisen kuluttamisen näkökulmista käsityössä [Knowledge, critique, action, responsibility - discussions about sustainability and ethical consumption in textile craft]. In: Kättä pidempää: Otteita käsityön tutkimuksesta ja käsitteellistämisestä (ed. by S. Karppinen, A. Kouhia and E. Syrjäläinen), pp. 48-61. Publications of Home Economics and Craft Science no 33. University of Helsinki, Helsinki. [Cited 2018 July 23]. Available from: http://hdl.handle.net/10138/43167.

Räisänen, R., Rissanen, M., Parviainen, E. and Suonsilta, H. (2017) Tekstiilien materiaalit [Textile materials]. Finn Lectura, Helsinki.

Scheid, F., Lambert, E., Maitra, W., Niestrath, M., Fäh, D., Portmann, C., Gorny, S. and Stamminger, R. (2016) Textile quality depletion due to household machine wash ways to measure and impacts of wash duration and temperature on textiles. Tenside, Surfactants, Detergents, 53(5): 438-443.

Schmitz, A. and Stamminger, R. (2014) Usage behavior and related energy consumption of European consumers for washing and drying. Energy Efficiency, 7: 937-954.

Spencer, J., Lilley, D. and Porter, S. (2015) The Implications of Cultural Differences in Laundry Behaviours for Design for Sustainable Behaviour: a Case Study between the UK, India and Brazil. International Journal of Sustainable Engineering, 8(3): 196-205.

This article is protected by copyright. All rights reserved. 
Statistics Finland (2018) [Cited 2018 March 21]. Available from: https://www.stat.fi/tup/suoluk/suoluk_vaesto_en.html.

Talvenmaa, P. (1998) Tekstiilit ja ympäristö [Textiles and environment]. Tekstiili ja vaateteollisuus, Tekstiili-ja jalkinetoimittajat ja Tekstiilikauppiaiden Liitto, Tampere.

UN (United Nations) (2018) Sustainable development goals. 17 goals to transform our world. [Cited 2018 July 23]. Available from: https://www.un.org/sustainabledevelopment/.

Vellamo (2018) Tampere Water. [Cited 2018 March 27]. Available from: https://vellamo.tampere.fi/en/about.

Wikipedia (2018) Spandex. [Cited 2018 March 29 2018]. Available from: https://en.wikipedia.org/wiki/Spandex.

Yates, L. and Evans, D. (2016) Dirtying Linen: Re-evaluating the sustainability of domestic laundry. Environmental Policy and Governance, 26: 101-115. DOI: 10.1002/eet.1704

YLE News (2018) Kasvissyöjät ovat lihansyöjiä tyytyväisempiä? Kestävät teot lisäävät elämän mielekkyyttä [Vegetarians are more content than carnivores? Sustainable deeds increase the meaningfulness of life]. YLE News 24.3.2018. [Cited 2018 April 4]. Available from: https://yle.fi/uutiset/3-10126711.

Yun, C., Patwary, S., LeHew, M. L. A. and Kim, J. (2017) Sustainable care of textile products and its environmental impact: Tumble-drying and ironing processes. Fibers and Polymers, 18(3): 590-596.

This article is protected by copyright. All rights reserved. 


\section{Figure legends}

Figure 1. Geographical areas of Finland.

Figure 2. Preferences when selecting detergent. The statements have been organised according to the highest mean (on a scale of $1-5$, fully disagree-fully agree, respectively), starting from the bottom. The $\mathrm{x}$-axis shows the percentage of the respondents in the particular opinion group $(\mathrm{N}=1841)$

Figure 3. Preferences for detergent dosage. Settings as in Figure 2.

Figure 4. Preferences that determine the amount of detergent used in washing. Settings as in Figure 2.

Figure 5. Places where laundry is washed. The statements have been organised according to the highest occurrence, starting from the bottom. The $\mathrm{x}$-axis shows the percentage of the respondents in the particular opinion group $(\mathrm{N}=1841)$, exact numbers are presented in Table 3.

Figure 6. Protective actions for garments and their frequencies. Settings as in Figure 5.

Figure 7. Reasons clothing was put into the laundry basket. Settings as in Figure 5.

Figure 8. Reasons for sorting laundry for washing. Settings as in Figure 5.

Figure 9. How full the washing machine is loaded.

Figure 10. Preferences for the selection of washing temperatures.

Figure 11. Preferences for drying laundry in winter (blue) and in summer (green).

Figure 12. Estimate of the factors that have had an effect on laundry practices in recent years. Settings as in Figure 5.

This article is protected by copyright. All rights reserved. 
Figure 13. Estimate of the impact of consumer's actions on the environment: how much the respondent has thought about the environment while laundering (top) and how much the respondent thinks about having an impact by own deeds (bottom).

\section{Table headings}

Table 1. The age distribution of the respondents.

\begin{tabular}{lcc}
\hline Age group [years] & $\%$ & Number \\
\hline $15-25$ & 6.2 & 115 \\
$26-35$ & 33.0 & 607 \\
$36-45$ & 28.8 & 530 \\
$46-55$ & 15.2 & 280 \\
$56-65$ & 8.6 & 159 \\
$66-87$ & 4.3 & 80 \\
No answer & 3.8 & 70 \\
\hline Total & 100.0 & 1841 \\
\hline
\end{tabular}

Table 2. Location of the respondents. No. corresponds to the areas in Figure 1.

\begin{tabular}{llcc}
\hline No. & Area & \% & Number \\
\hline 1a & Helsinki metropolitan area & 30.6 & 563 \\
& (Helsinki, Espoo, Vantaa, Kauniainen) & & \\
1 & Rest of southern Finland & 22.5 & 414 \\
2 & Western Finland & 27.1 & 500 \\
3 & Eastern Finland & 9.0 & 165 \\
4 & Oulu area & 8.0 & 147 \\
5 & Lapland & 2.8 & 52 \\
6 & Aland & 0.0 & 0 \\
\hline & Total & 100.0 & 1841 \\
\hline
\end{tabular}

This article is protected by copyright. All rights reserved. 
Table 3. Places where laundry is washed $(\mathrm{N}=1841)$. Table is visualised in Figure 5.

\begin{tabular}{lccrrrr}
\hline Place & $\begin{array}{c}\text { Weekly } \\
\text { or more } \\
\text { often } \\
\%\end{array}$ & $\begin{array}{c}\text { Couple } \\
\text { times a } \\
\text { month } \\
\%\end{array}$ & $\begin{array}{c}\text { Once a } \\
\text { month } \\
\%\end{array}$ & $\begin{array}{c}\text { Once or } \\
\text { couple } \\
\text { times a } \\
\text { year } \\
\text { \% }\end{array}$ & $\begin{array}{c}\text { Less } \\
\text { than } \\
\text { once a } \\
\text { year } \\
\text { \% }\end{array}$ & $\begin{array}{c}\text { Never } \\
\%\end{array}$ \\
\hline At launderette & 0.2 & 0.0 & 0.1 & 3.4 & 5.7 & 90.7 \\
Somewhere else & 0.5 & 0.7 & 1.4 & 13.3 & 9.5 & 74.6 \\
$\begin{array}{l}\text { At cleaners } \\
\text { At laundry in the }\end{array}$ & 0.2 & 0.3 & 1.8 & 14.3 & 22.0 & 61.5 \\
housing cooperative & 4.6 & 3.4 & 2.6 & 6.0 & 3.9 & 79.5 \\
At home with hand & 3.9 & 13.2 & 17.0 & 40.4 & 13.0 & 12.5 \\
wash & & & & & & \\
At home with own & 91.7 & 3.0 & 0.7 & 0.4 & 0.2 & 4.1 \\
machine & & & & & & \\
\hline
\end{tabular}

This article is protected by copyright. All rights reserved. 


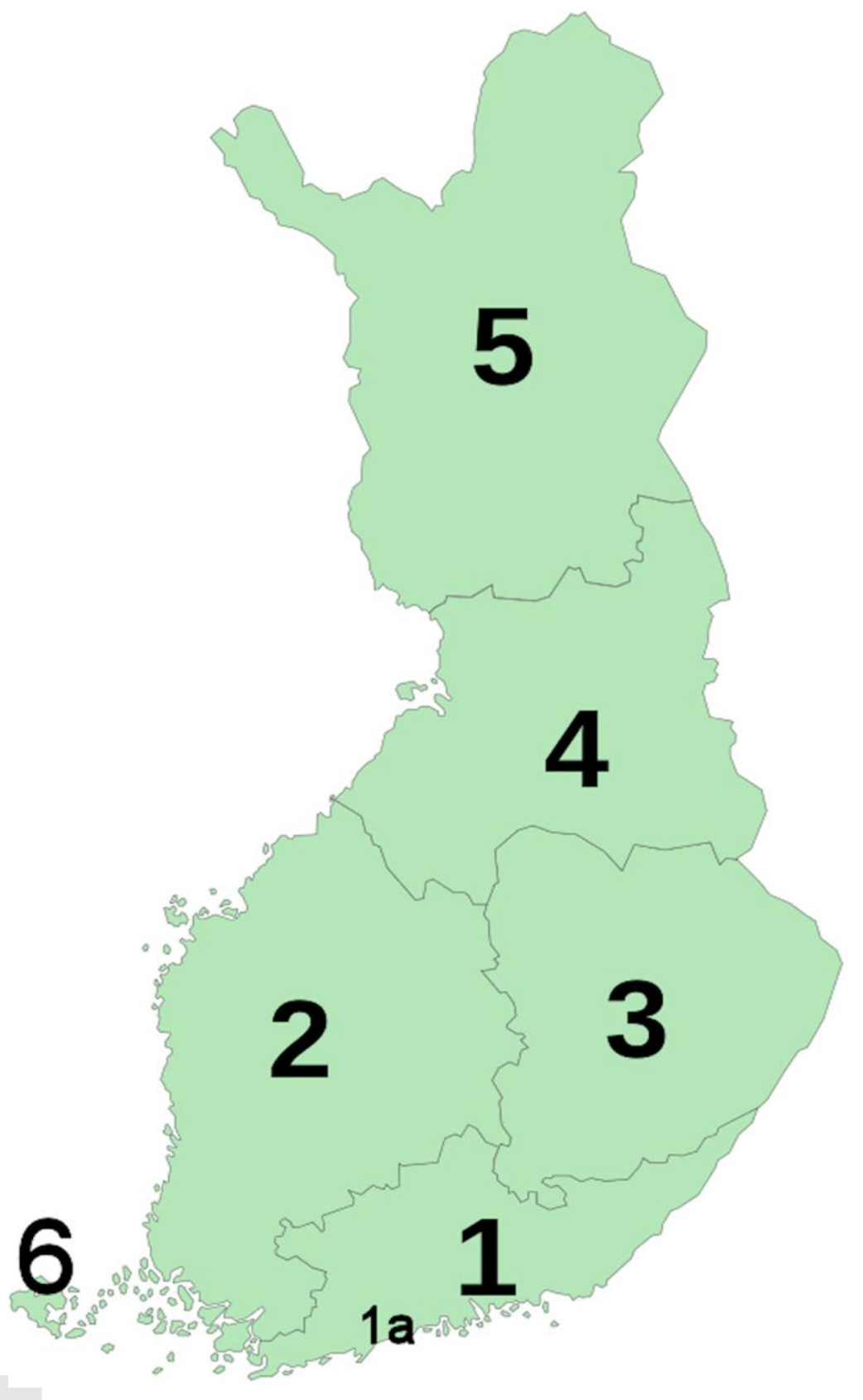

This article is protected by copyright. All rights reserved. 

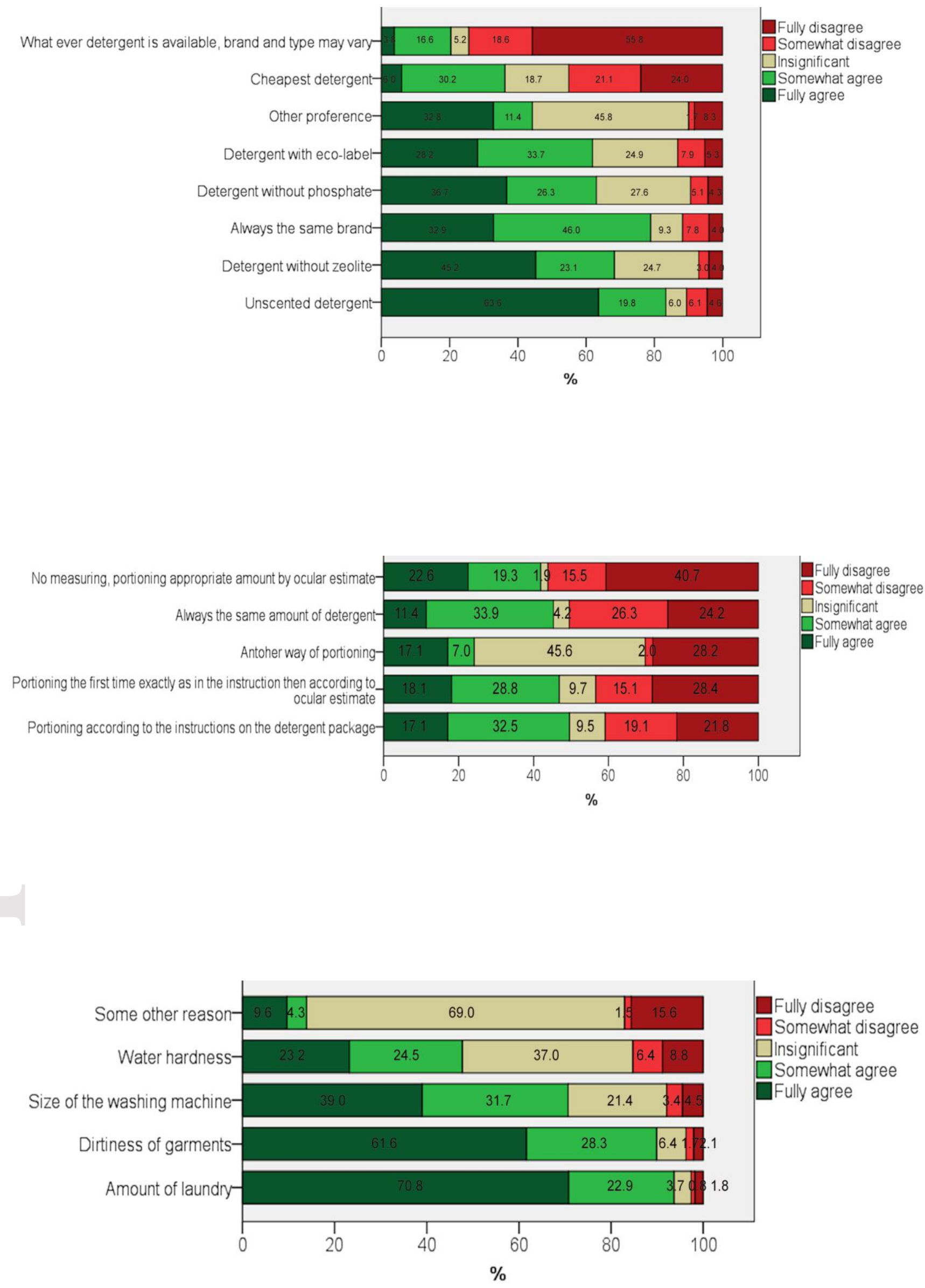

This article is protected by copyright. All rights reserved. 

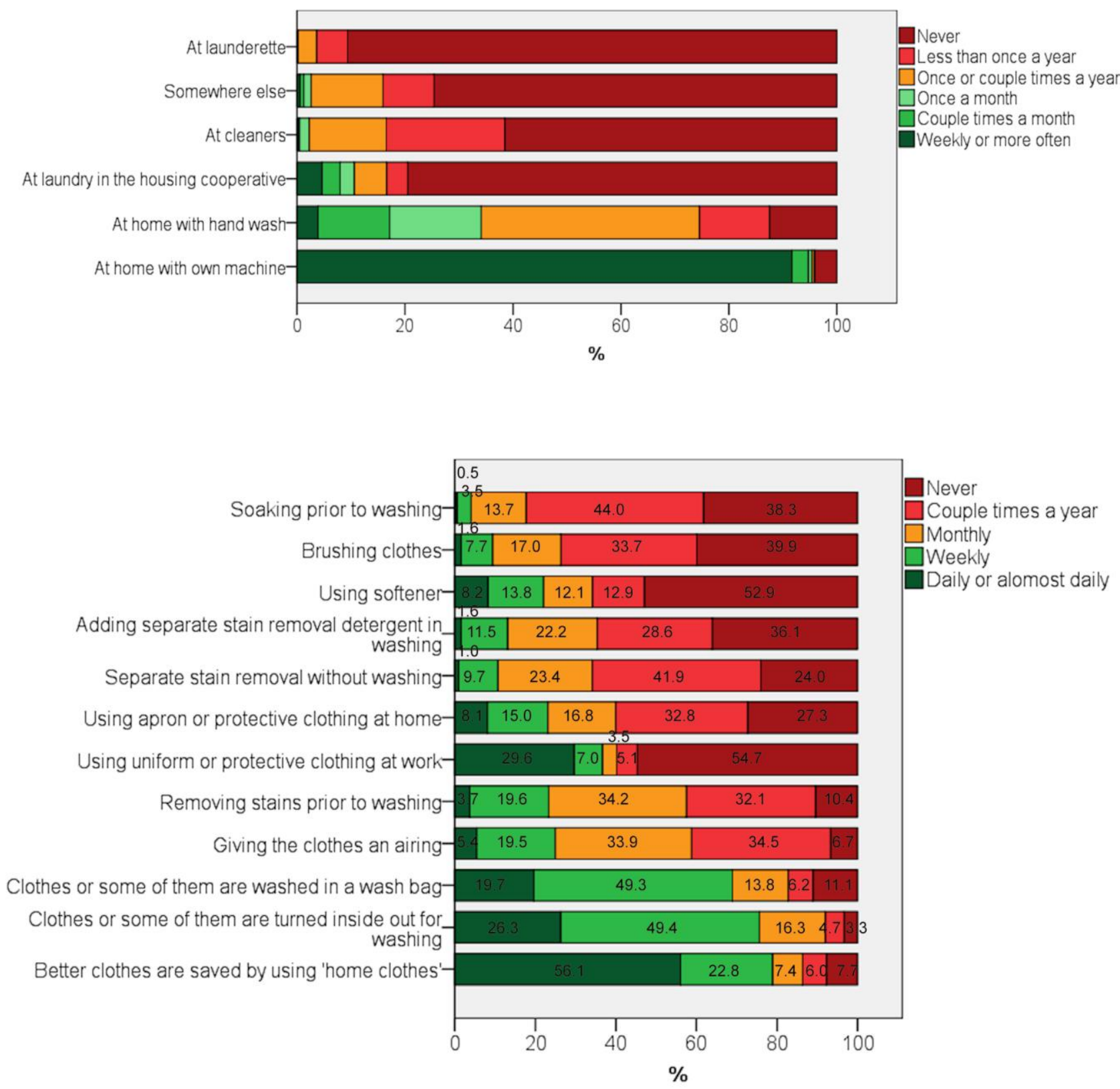

This article is protected by copyright. All rights reserved. 

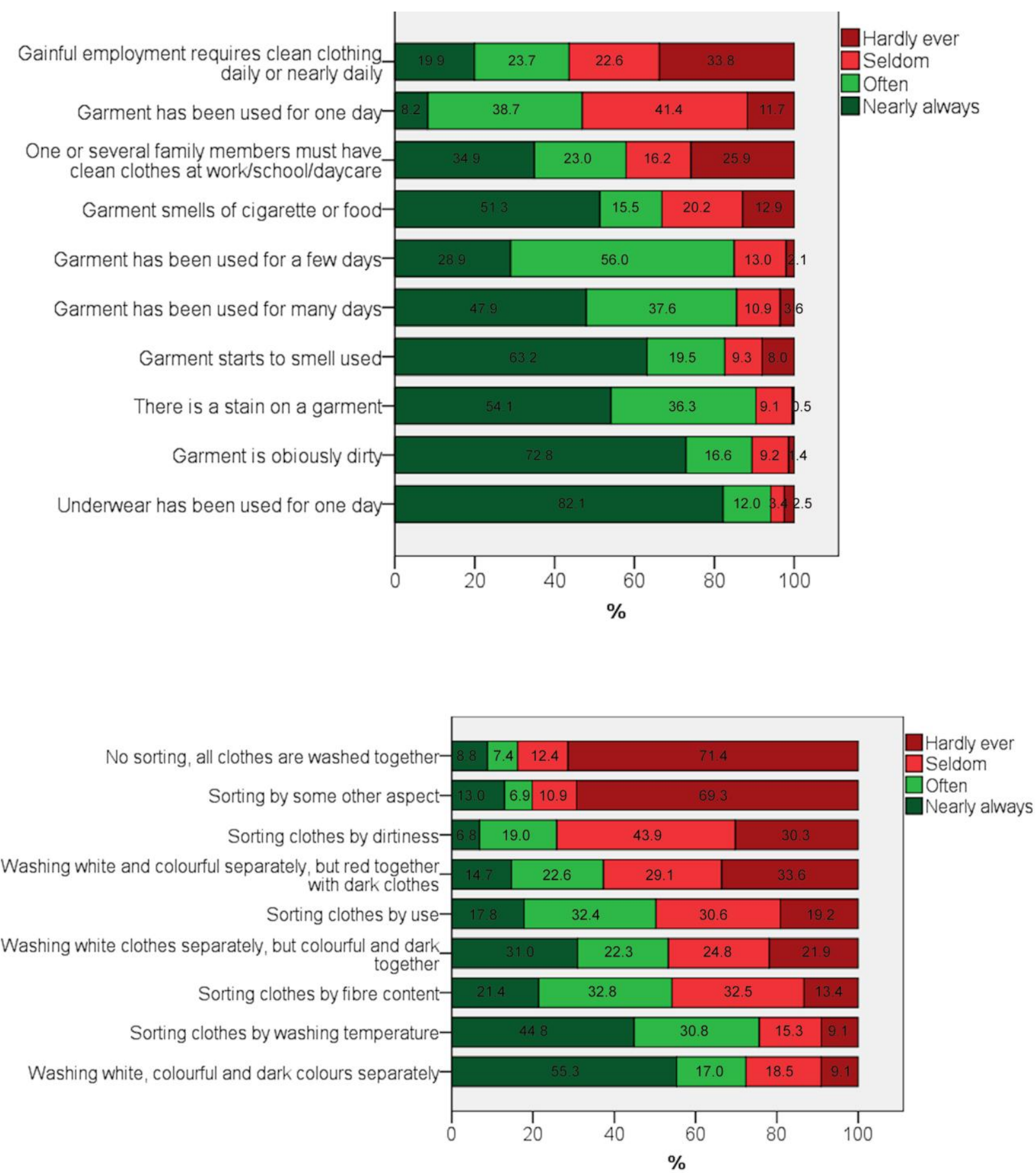

This article is protected by copyright. All rights reserved. 

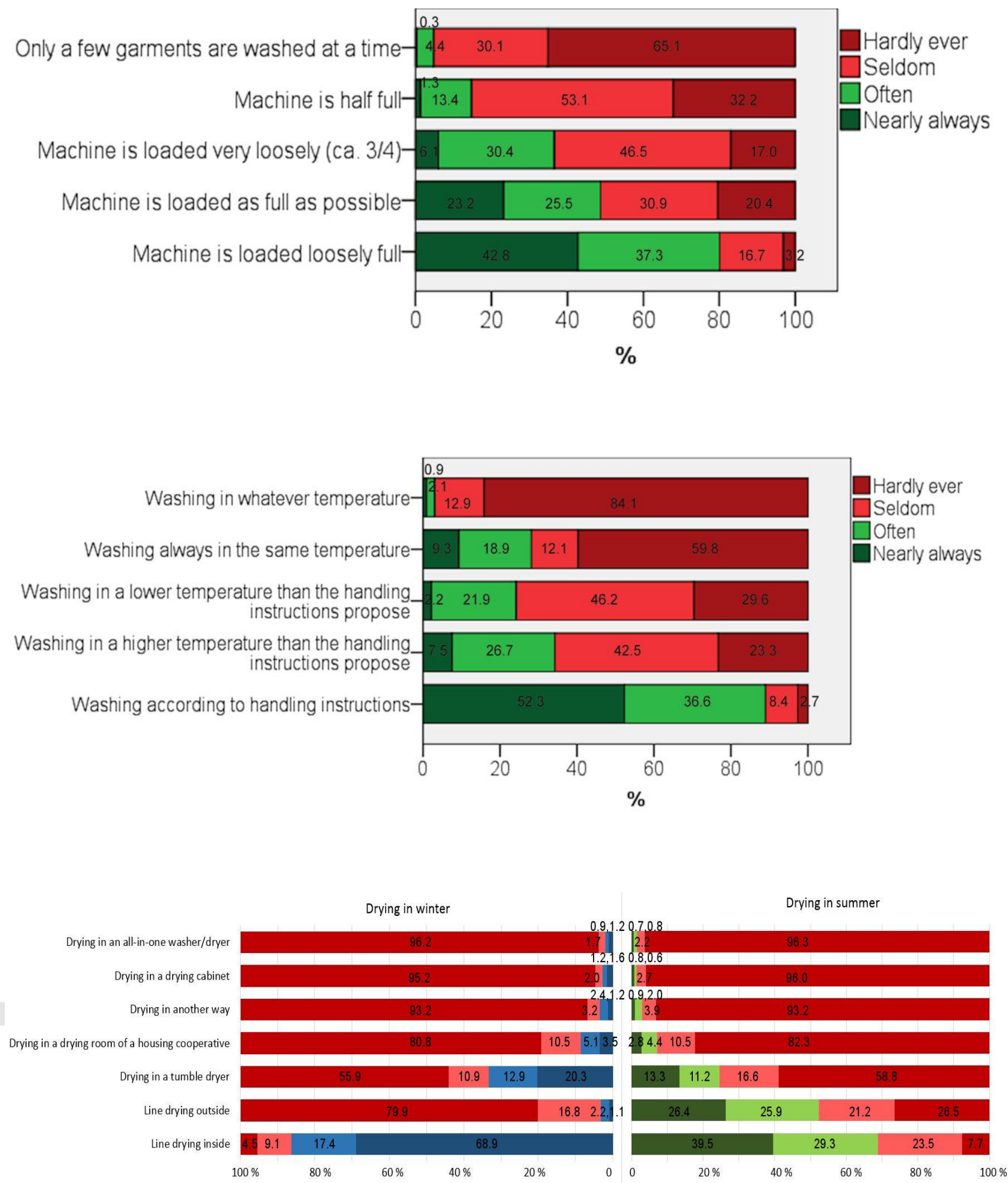

This article is protected by copyright. All rights reserved. 


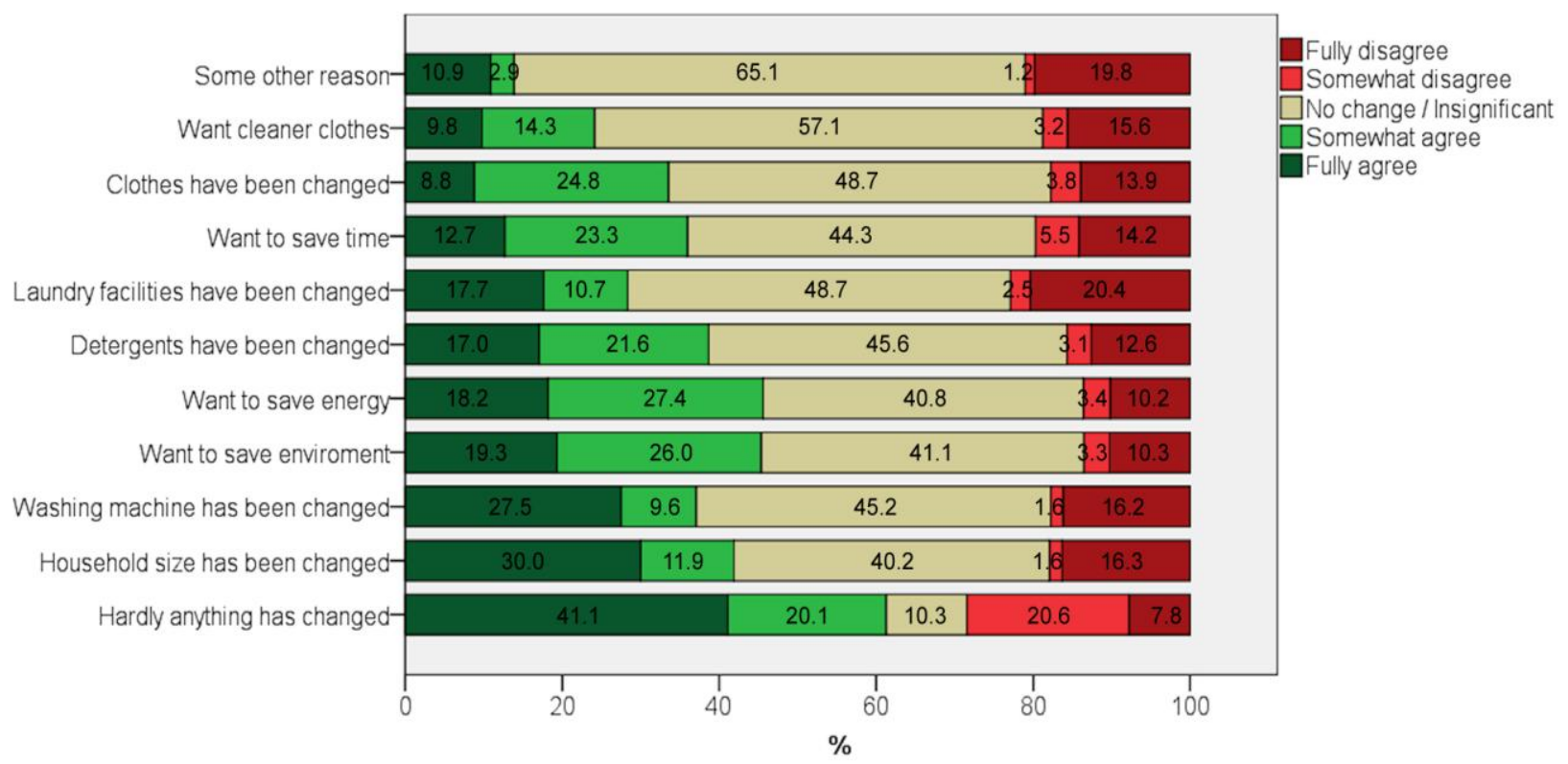
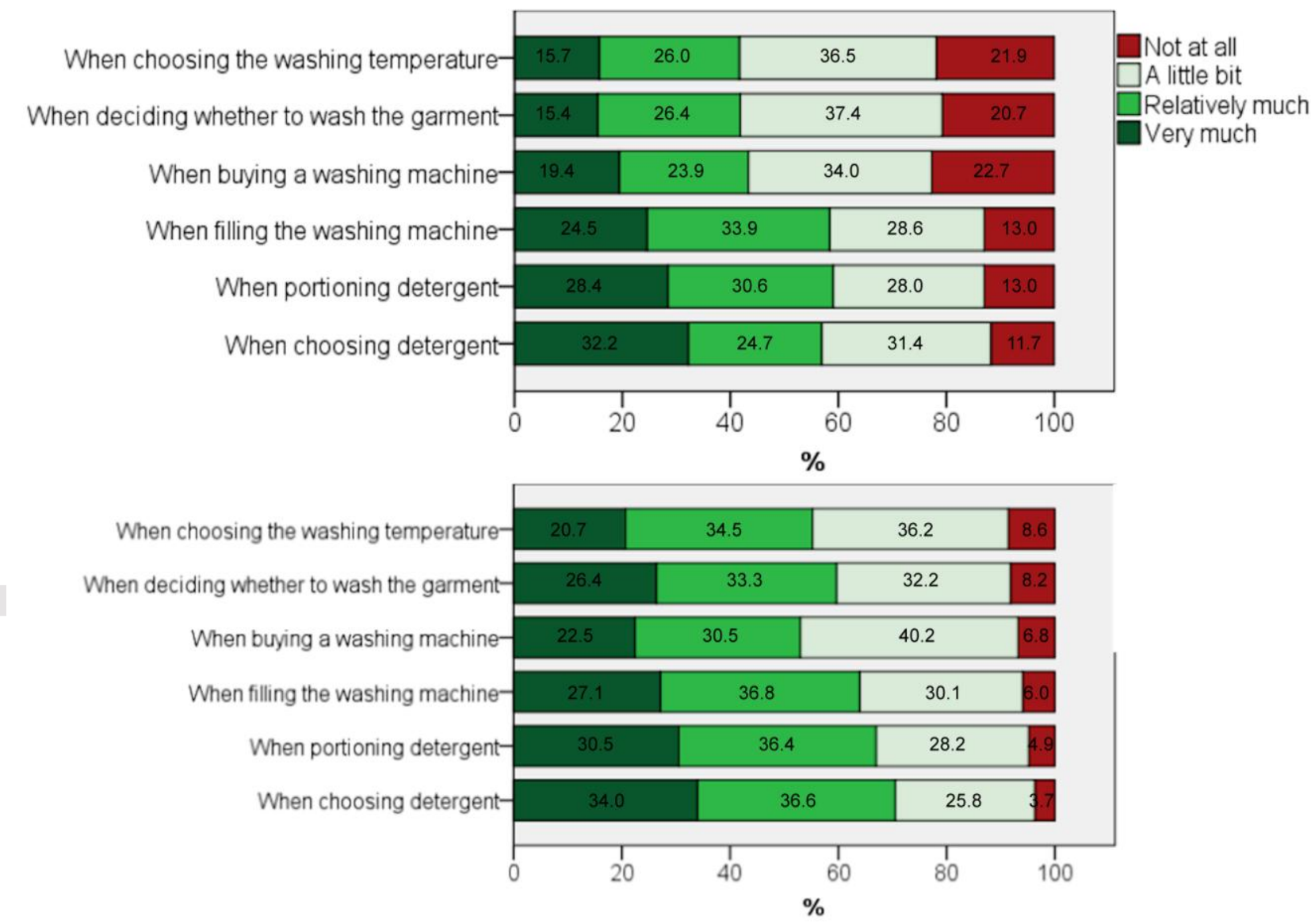

This article is protected by copyright. All rights reserved. 